\title{
The organization of management accounting as a mechanism to improve the efficiency of agricultural enterprises
}

\author{
$Y$ U. N. Kudryashova ${ }^{1,2, *}, T$. G. Lazareva ${ }^{1}, T . N$. Makushina $^{1}$, and $Y u$. V. Chernova ${ }^{1}$ \\ ${ }^{1}$ Samara State Agrarian University, 446442 Kinel, Samara region, Russia \\ ${ }^{2}$ Samara State University of Management "International Market Institute," 443030 Samara, Russia
}

\begin{abstract}
The article discusses a comparative analysis of full cost systems, "direct cost" and "standard cost". A comparative characteristic and features of using the accrual method and the cash basis method in management accounting are given. A practical example illustrates the advantages of using the cash method and the accrual method in calculating marginal income. The necessity of reflecting the marginal profit on a separate account 92 "Marginal profit (loss)" is substantiated and, in accordance with this, correspondence of accounts on the formation of marginal income using various methods is proposed. A new methodology for calculating CVP analysis indicators is proposed.
\end{abstract}

\section{Introduction}

One of the areas of development of management accounting is the use of the "kaizen-costing" system. The essence of the Kaisen-costing system is to provide the necessary level of product cost and search for ways to reduce costs to a certain target level, which ensures production profitability. The use of kaizen philosophy is based on the principle: "... the production life cycle should be longer than the product life cycle" [1].

The aim of the Kaisen-costing system is to improve the activities of the enterprise as a whole and its centers of responsibility by mobilizing internal reserves without attracting large investments from outside. The main task of kaisen-costing at the production stage is to minimize the difference between the target and actual cost of production in general and for individual stages of production and cost items.

The financial management process in the kaizencosting system is closely related to the business planning process. "Kaisen" in relation to human activities in the workplace is a continuous improvement of the process in which everyone participates: from the leader to the worker. In addition, there is an active use of nonfinancial information to motivate employees to improve quality and time indicators. At the heart of the solution of the kaizen problems is the planning of the enterprise, carried out based on the actually achieved production indicators and performed production processes. The business planning process is brought to the immediate executors of business plans (profit and loss) and involves the development of their own annual budget. The development of business plans can be carried out either from top to bottom (based on the target parameters outlined by management) or from bottom to top (when units form their plans). The business planning process can be carried out on the one hand by the company's management when common goals are formulated that follow from the company's strategy and market forecasts, and then based on these goals, a real budget is developed at the level of structural units [2].

The production units, taking into account the projected sales volumes, form the production program and on its basis calculate cost budgets (budget for the use of materials, budget for direct labor costs, etc.). Subsequently, based on these indicators, the total planned costs are estimated and a profit and loss forecast is made. His data are compared with indicators of target cost and profit and determine the difference, which becomes the basis for the Kaisen task for the coming period [3].

Indicators of targeted cost reduction are set in the context of their articles, which are previously subdivided into variables and constants. Considerable attention should be paid to variable costs, which are directly dependent on the level of business activity of the enterprise. Fixed costs are subsequently systematized for each unit, and then, taking into account the set kaizen tasks, are included in the annual budget.

It should be noted that the use of "kaizen-costing" does not mean a complete replacement by it of other financial systems. Typically, companies combine the use of the kaizen-costing system with the standard-cost or direct-cost system for financial management.

With external acquaintance, the "kaizen-costing" system is close to the "standard-costing" system, due to the fact that in both systems the basis for comparison are

\footnotetext{
* Corresponding author: Kudryashova.julya@yandex.ru
} 
standards (norms) [4]. With a more detailed comparison, the differences become apparent (table 1).

Nevertheless, the idea of controlling costs and results by comparing the achieved (actual) results with certain target settings is common for standard-costing and Kaizen-costing systems.

Table 1. Differences between the Kaisen-Costing and Standard-Costing systems

\begin{tabular}{|c|c|c|c|}
\hline № & Feature & Kaisen-Costing & $\begin{array}{c}\text { Standard- } \\
\text { Costing }\end{array}$ \\
\hline 1. & Key idea & $\begin{array}{c}\text { Achieving a } \\
\text { predetermined } \\
\text { level of cost } \\
\text { reduction, which } \\
\text { is constantly } \\
\text { being adjusted in } \\
\text { the direction of } \\
\text { its reduction. }\end{array}$ & $\begin{array}{c}\text { Achieving a } \\
\text { predetermined } \\
\text { level of cost } \\
\text { reduction, which } \\
\text { is constantly } \\
\text { adjusted in the } \\
\text { direction of its } \\
\text { reduction. }\end{array}$ \\
\hline 2. & Functionality & $\begin{array}{c}\text { It is a tool to } \\
\text { reduce costs. }\end{array}$ & $\begin{array}{c}\text { It is mainly used } \\
\text { for cost control } \\
\text { and performance } \\
\text { evaluation. }\end{array}$ \\
\hline 3. & $\begin{array}{c}\text { Comparison } \\
\text { area }\end{array}$ & $\begin{array}{c}\text { Comparison of } \\
\text { the target cost } \\
\text { reduction with } \\
\text { the actual } \\
\text { amounts of their } \\
\text { savings. }\end{array}$ & $\begin{array}{c}\text { Typically, actual } \\
\text { and standard } \\
\text { costs are } \\
\text { compared. }\end{array}$ \\
\hline
\end{tabular}

The Kaisen-costing system is based on the distribution of overhead costs for fixed and variable, which combines it with the direct-costing system that calculates the truncated cost, that is, calculated based on their variable costs or direct variable costs and variable overhead costs. Unlike the full cost accounting system, the variable cost accounting system provides for the use of rough, preliminary estimates [5]. One of the most effective indicators of this system is the marginal income.

The Kaizen-costing system is also different from traditional systems operating in mass production. The emphasis in Kaizen-costing is on providing information to employees and motivating them to reduce costs, rather than calculating a more accurate cost of production. Cost reduction acts as a group, not a personal responsibility. That is why the process of subsequent cost analysis is phased and carried out at the level of each local unit or batch of products participating in the Kaizen program.

- supporting a policy of constant cost reduction for the production of new types of products;

- the mood of the team to achieve their goals (timely receive the desired profit);

- a cost management system in which it becomes possible to compare target costs with achieved ones;

- comprehensive cost analysis at all stages of production;

- assistance in the development and implementation of the latest technologies in the production process;

- the impact on the continuous improvement of products and / or services;

- cooperation of all departments of the organization $[6,7]$.
However, it is necessary to note the negative aspects in the application of the concept under consideration. First, due to the fact that the formulation and implementation of the Kaizen task is closely related to the process of business planning, the practical implementation of the Kaizen task is possible provided that the organization and its structural units use the budget method of planning. Secondly, it is necessary to remember that "Kaizen-costing" can operate only in enterprises where the current cost accounting model allows you to quickly obtain current results. For most domestic enterprises, this will be a significant limiting factor in the application of this concept. In any case, we will have to start with the creation of an effective cost accounting system $[8,9]$.

\section{Materials and methods}

The subject of scientific research was the organization of management accounting at production enterprises with the aim of developing recommendations for improving the accounting process in terms of cost accounting and calculating the cost of production, as well as the formation of accounting indicators that facilitate the

The object of the study was the agro-industrial enterprises of the Samara region. The information base for the study was the registers of synthetic, analytical accounting and reporting of the Severnyj Klyuch, the joint-stock company in the Pohvistnevsky district. Severnyj Klyuch, JSC is engaged in the production, processing and sale of agricultural products, specializing in the pig industry. Severnyj Klyuch, JSC consists of five departments for fattening pigs and cattle, and for growing grain and leguminous crops. The farm has a feeding complex for 11,400 heads, a brood farm for 1,300 sows, 3 feed plants with a capacity of 150 tons per day, typical artificial insemination centers, 6 grain stores. The enterprise is financially stable and solvent. Accounting is automated.

In the course of scientific research, a hypothesis was put forward on the development of managerial accounting in the framework of the "kaizen-costing" concept. It is proposed to use the marginal income calculated taking into account the fact of payment of mutual settlements to assess the effectiveness of the enterprise. As a result, it is proposed to introduce changes in the methodology for recording marginal income in the system of accounting accounts.

In the process of scientific research, the following methods were used: monographic, economic-statistical, abstract technology.

\section{Results and discussion}

The Kaisen-costing system differs from generally accepted approaches, techniques, terminology in terms of accounting and cost allocation. One of the indicators of managerial accounting that characterize the effectiveness of the enterprise is marginal income. In the economic literature, marginal income is defined as the difference between revenue and variable costs. However, 
in practice, modern enterprises may not receive revenue in this reporting period or may not receive it in full. Therefore, for managerial accounting, the use of accrued revenue as an analytical indicator is not always informative.

Variable costs include the wages of the main production workers who are on piecework wages, and the variable part of the wages of the administrative and managerial staff who are on time wages (if the accounting policy provides for the distribution of overhead costs for fixed and variable parts), and also material costs. However, the company may have unpaid salaries to suppliers. In this regard, it can be noted that variable costs calculated by the accrual method do not disclose full information [10]. Therefore, we can recommend the calculation of "paid variable costs" and "paid fixed costs" (table. 2).

Table 2. Paid variable and fixed costs

\begin{tabular}{|l|l|l|}
\hline \multicolumn{1}{|c|}{ Costs } & Paid variable costs & Paid fixed costs \\
\hline $\begin{array}{l}\text { Material } \\
\text { costs }\end{array}$ & $\begin{array}{l}\text { Accrued direct costs } \\
\times \text { Avg\%LD }\end{array}$ & $\begin{array}{l}\text { Accrued overhead } \\
\times \text { Avg\%LD }\end{array}$ \\
\hline $\begin{array}{l}\text { Labor } \\
\text { costs }\end{array}$ & $\begin{array}{l}\text { Paid wages of } \\
\text { employees on piece- } \\
\text { rate wages }\end{array}$ & $\begin{array}{l}\text { Paid wages of } \\
\text { administrative and } \\
\text { managerial personnel } \\
\text { on time wage }\end{array}$ \\
\hline $\begin{array}{l}\text { Other } \\
\text { expenses }\end{array}$ & $\begin{array}{l}\text { Accrued variables } \\
\text { other expenses } \times \\
\text { Avg\% }\end{array}$ & $\begin{array}{l}\text { Accrued fixed other } \\
\text { expenses } \\
\times \text { Avg \% LD }\end{array}$ \\
\hline
\end{tabular}

Avg\%LD - the average payable percentage of loan debts, which means the share of paid payables for the period in question in its accrued amount.

Depreciation costs are not reflected in the table. Depreciation charges relate to variable costs only when they are charged according to the method of write-off of value in proportion to the volume of production. Most businesses charge depreciation on a straight-line basis. In this regard, this type of cost as part of variable costs can be neglected.

Thus, the marginal income from the position of the cash method can be calculated as the difference between the revenue received (paid receivables) and paid variable costs [11].

In this regard, in management accounting, it is recommended to introduce the concepts: marginal income with the accrual method and marginal income with the cash method.

The cash-based margin income from an economic point of view means the amount that can be used to pay off fixed costs to be paid. From a practical point of view, this indicator will contribute to more informed management decisions in the short term.

In this regard, it is recommended to make changes in the management accounting methodology. In the organization's accounting system, it is necessary to enter an active-passive account 92 "Marginal profit (loss)", as well as off-balance sheet accounts:

- account 012 "Received revenue";

- account 013 "Paid variable costs";

- account 014 "Marginal income in cash method";

- account 015 "Paid fixed costs";
- account 016 "The difference between the marginal income for the cash method and paid fixed costs".

The cash income margin method is a much stricter indicator than the marginal income method with the accrual method.

The introduction of account 92 "Marginal profit (loss)" entails the need to amend the Instructions for the application of "the Chart of Accounts for the accounting of financial and economic activities of organizations". Recommended correspondence of accounts in account 92 "Marginal profit (los )" is presented in table 3.

Subaccounts may be opened to account 92 "Marginal profit (loss)":

92-1 "Marginal profit (loss)";

92-2 "Fixed costs";

92-3 "Profit / loss on sales".

Records on sub-accounts 92-1 "Marginal profit (loss)", 92-2 "Fixed costs" are made cumulatively during the reporting year. A monthly comparison of the total debit turnover in subaccount 92-2 "Fixed Costs" and the credit turnover in subaccount 92-1 "Marginal Profit (Loss)" determines the financial result (profit or loss) from sales for the reporting month. This financial result is monthly (final turnover) is debited from subaccount 92-3 "Profit / loss from sales" to account 99 "Profit and loss" (if the accounting policy reflects the option providing for the calculation of margin profit (loss). Thus, the synthetic account 92 "Marginal profit (loss)" has no balance at the reporting date. Analytical accounting is carried out in the context of orders, objects, etc.

Table 3. Recommended correspondence of accounts in accounts 92 "Marginal profit (loss)"

\begin{tabular}{|c|c|c|c|c|}
\hline \multirow{2}{*}{$\begin{array}{l}\text { Account } \\
\text { Number } \\
\text { and } \\
\text { Name }\end{array}$} & \multirow{2}{*}{$\begin{array}{c}\text { Assignmen } \\
\mathrm{t}\end{array}$} & \multirow{2}{*}{$\begin{array}{c}\text { The } \\
\text { Name of } \\
\text { the } \\
\text { Operatio } \\
n\end{array}$} & \multicolumn{2}{|c|}{$\begin{array}{c}\text { Account } \\
\text { Correspondence }\end{array}$} \\
\hline & & & Debit & Credit \\
\hline \multirow{5}{*}{$\begin{array}{c}92 \\
\text { "Margina } \\
\text { 1 profit } \\
\text { (loss)" }\end{array}$} & \multirow{5}{*}{$\begin{array}{l}\text { intended to } \\
\text { account for } \\
\text { the amount } \\
\text { of marginal } \\
\text { profit } \\
\text { (loss) }\end{array}$} & $\begin{array}{l}\text { Margina } \\
\text { l profit is } \\
\text { reflected }\end{array}$ & $\begin{array}{c}90 \\
\text { "Sales" }\end{array}$ & $\begin{array}{c}\text { 92-1 } \\
\text { "Margina } \\
\text { 1 profit } \\
\text { (loss)" }\end{array}$ \\
\hline & & $\begin{array}{l}\text { Marginal } \\
\text { loss is } \\
\text { reflected }\end{array}$ & $\begin{array}{c}\text { 92-1 } \\
\text { "Margina } \\
\text { 1 profit } \\
\text { (loss)" }\end{array}$ & $\begin{array}{c}90 \\
\text { "Sales" }\end{array}$ \\
\hline & & $\begin{array}{l}\text { Written } \\
\text { off fixed } \\
\text { expenses } \\
\text { for } \\
\text { financial } \\
\text { result } \\
\end{array}$ & $\begin{array}{l}92-2 \\
\text { 'Fixed } \\
\text { costs' }\end{array}$ & $\begin{array}{c}26 \\
\text { "General } \\
\text { expenses } \\
\text {," }\end{array}$ \\
\hline & & $\begin{array}{l}\text { Revenue } \\
\text { from } \\
\text { sales is } \\
\text { revealed }\end{array}$ & $\begin{array}{c}\text { 92-3 } \\
\text { "Profit } \\
\text { (loss) } \\
\text { from } \\
\text { sales" }\end{array}$ & $\begin{array}{l}99 \text { "Profit } \\
\text { and loss" }\end{array}$ \\
\hline & & $\begin{array}{c}\text { Loss } \\
\text { from } \\
\text { sales is } \\
\text { revealed }\end{array}$ & $\begin{array}{l}99 \text { "Profit } \\
\text { and loss" }\end{array}$ & $\begin{array}{c}92 \text { "Profit } \\
\text { (loss) } \\
\text { from } \\
\text { sales" }\end{array}$ \\
\hline
\end{tabular}


The use of the marginal income indicator with the cash method will lead to the transformation of breakeven analysis formulas.

$$
\mathrm{R}_{\mathrm{m}}=\frac{\text { cashincomemarginmethod }}{\text { actualreceivedrevenue }}
$$

where $R_{m}$ is a margin ratio.

$\mathrm{B}_{\mathrm{p}}=\frac{\text { paidfixedexpensesforthe period }}{\text { Cashmarginincom,units }}$

where $\mathrm{B}_{\mathrm{p}}$ is a breakeven point, unit.

$$
\mathrm{Be}_{\mathrm{p}}=\frac{\text { fixedpaidcosts }}{\text { marginratio }}
$$

where $\mathrm{Be}_{\mathrm{p}}$ is a break-even revenue, rub.

$F_{\mathrm{sm}}=$ Expected Sales - Breakeven sales volume (4),

where $\mathrm{F}_{\mathrm{sm}}$ is a financial safety margin.

$$
\mathrm{OL}=\frac{\text { Cashmarginincome }}{\text { Cashprofit }}
$$

where OL is an impact of the operating leverage.

Consider the example of agro-industrial enterprise Severnyj Klyuch, JSC the impact of the cash method and accrual method on indicators characterizing the economic efficiency of the enterprise (table. 4).

Table 4. The results of applying breakeven analysis formulas

\begin{tabular}{|c|c|c|}
\hline Index & $\begin{array}{c}\text { Accrual } \\
\text { method }\end{array}$ & $\begin{array}{c}\text { Cash } \\
\text { method }\end{array}$ \\
\hline $\begin{array}{c}\text { Revenues, RUB, in } \\
\text { thousands. }\end{array}$ & 432192 & 384242 \\
\hline $\begin{array}{c}\text { Variable costs, RUB, in } \\
\text { thousands. }\end{array}$ & 322062 & 306256 \\
\hline $\begin{array}{c}\text { Variable costs per unit of } \\
\text { output, RUB, in thousands. }\end{array}$ & 4.77 & 4.56 \\
\hline $\begin{array}{c}\text { Marginal income, RUB, in } \\
\text { thousands. }\end{array}$ & 110130 & 77986 \\
\hline $\begin{array}{c}\text { Marginal income per unit, } \\
\text { RUB, in thousands. }\end{array}$ & 1.33 & 1.15 \\
\hline $\begin{array}{c}\text { Fixed costs, RUB, in } \\
\text { thousands. }\end{array}$ & 92750 & 73126 \\
\hline $\begin{array}{c}\text { Profit from sales, RUB, in } \\
\text { thousands. }\end{array}$ & 17380 & 4860 \\
\hline Profit margin ratio MD / V & 0.25 & 6.2 \\
\hline Profitability threshold, c & 61754 & 64713 \\
\hline $\begin{array}{c}\text { Revenue at the breakeven } \\
\text { point, RUB, in thousands. }\end{array}$ & 395226 & 368217 \\
\hline $\begin{array}{c}\text { The stock of financial } \\
\text { strength, c. }\end{array}$ & 5800 & 2841 \\
\hline $\begin{array}{c}\text { Stock of financial strength, } \\
\text { RUB, in thousands. }\end{array}$ & 36966 & 16025 \\
\hline $\begin{array}{c}\text { The impact of the operating } \\
\text { leverage. }\end{array}$ & 6.34 & 16.05 \\
\hline
\end{tabular}

\section{Conclusion}

The analysis allows us to draw the following conclusions. The cash method reflects a stronger relationship between revenue and profit from sales, but at the same time we get more "tough" values of indicators. In the cash method, performance indicators of an enterprise vary depending on the percentage of repayment of receivables and payables. The percentage change in sales profit with the accrual method is 6.34, and with the cash method it is 16.05 . The cash method clearly illustrates that a change in revenue of at least $1 \%$ leads to significant changes in sales profit, which entails the adoption of informed management decisions in the field of pricing and changes in sales revenue.

Thus, it is necessary to take into account the possibility of using the cash method when putting into practice the concept of kaizen-costing. This approach allows you to generate more reliable information, and, therefore, should be included in the elements of the order on accounting policies, developed for the purpose of management accounting. The concept of kaizen-costing contributes to the adoption of operational, economically sound management decisions that contribute to increasing the efficiency of agricultural enterprises.

\section{References}

1. L.I. Khoruzhy, Y.N. Katkov, V.I. Khoruzhy, K.A. Dzhikiya, E.I. Stepanenko, Current approaches to assessing and enhancing the efficiency of managerial decisions in agrarian organizations Astra Salvensis 6, 835-845 (2018)

2. E.M. Akhmetshin, N.A. Prodanova, S.S. Shevchenko, I.P. Ratnikova, Y.Y. Gazizyanova, O.N. Zherelina, Current Issues of Corporate Integrated Reporting Development in Russia European Research Studies J. 21(Special Issue 3), 142-153 (2018)

3. O. V. Mamai, A. A. Penkin, I. S. Kurmaeva, A. L. Mishanin, S. V. Pertsev, Government regulation of the economy: why it is effective Research $\mathrm{J}$. of Pharmaceutical, Biological and Chemical Sciences 9(5), 1269 -1275 (2018)

4. R.A. Alborov, S.M. Kontsevaya, G.S. Klychova, V.P. Kuznetsov, The development of management and strategic management accounting in agriculture J. of Engineering and Applied Sciences 12(19), 4979-4984 (2017)

5. E.M. Akhmetshin, V.L. Vasilev, D.S. Mironov, A.V. Yumashev, A.S. Puryaev, V.V. Lvov, Innovation process and the control function in management European Research Studies J. 1(1), 663-674 (2018)

6. Ya. G. Shtefan, L.A. Zimakova, M.A. Vakhrushina, V.B. Malitskaya, M.B. Chirkova, Stage of economic substation analysis and modeling for the meat processing companies prise strategy Espacios 38(49), 16 (2017)

7. G.D. Snigireva, M.A. Kazakova, I.L. Sennikova, M.V. Palkina, V.I. Bespyatyh, O.A. Mironova, A conceptual approach to the assessment of regional innovation environment factors based on the index method Espacios 38(54), 30 (2017)

8. S.R. Kontsevaya, L.I. Khoruzhy, I.V. Kharcheva, I.V. Makunina, R.V. Kostina, Taking the managerial decisions at the enterprise in the age of agriculture globalization in Russian Federation in 
Agrarian perspectives XXIV - Global Agribusiness and Rural Economy Conf. Proc. 216-223 (2015)

9. E.M. Akhmetshin, V.L. Vasilev, D.S. Mironov, E.I. Zatsarinnaya, M.V. Romanova, A.V. Yumashev Internal control system in enterprise management: analysis and interaction matrices European Research Studies J. 21(2), 728-740 (2018)

10. J.V. Ragulina, A.E. Suglobov, M.V. Melnik, Transformation of the role of a man in the system of entrepreneurship in the process of digitalization of the Russian economy Quality - Access to Success 19(S2), 171-175 (2018)

11. E. A. Osadchy, E. M. Akhmetshin, E. F. Amirova, T. N. Bochkareva, Yu. Yu. Gazizyanova, A. V. Yumashev, Financial statements of a company as an information base for decision-making in a transforming economy European Research Studies J. 21(2), 339-350 (2018) 